\section{UNCLASSIFIED}

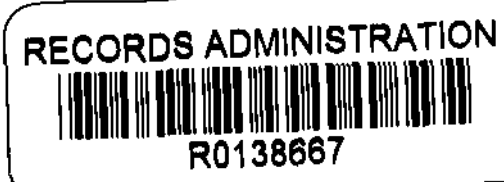

\section{DP - 110}

Instrumentation

Fख

\title{
SRP SCINTILLATION COUNTERS
}

\author{
by \\ C. A. Prohaska
}

Instrument Development Division

March 1955

E. I. du Pont de Nemours \& Co.

Explosives Department - Atomic Energy Division Technical Division - Savannah River Laboratory 


\section{SRP SCINTILLATION COUNTERS}

by

C. A. Prohaska

Instrument Development Division

March 1955

E. I. du Pont de Nemours \& Co.

Explosives Department - Atomic Energy Division

Technical Division - Savannah River Laboratory

Printed for

The United States Atom1c Energy Commission Contract $\operatorname{AT}(07-2)-1$ 


\section{INTERNAL DISTRIBUTION}

No. of Copies

(5) AEC, SROO Augusta, Ga.

(1) R. M. Evans -

B. H. Mackey W. Cole - M. Hilmiton AED

(1) J. E. Cole - M. H. Smith - "

(1) W. C. Kay - H. Worthington "

(1) S. I. Winde Engineering Department

$\left\{\begin{array}{l}\text { I) } \\ \text { J) D. Ellett } \\ \text { W. P. Overbeck } \\ \text { T. C. Evans - J. D. Cist } \\ \text { I) H. J. Bowman - W. M. Sloan " " } \\ \text { I) PRD File }\end{array}\right.$

(1) M. H. Wahl -

(I) J. W. J. Wende Sroach - L. M. Arnett "

I) J. N. Wilson "

1) J. I. Hyde "

(1) C. A. Prohaska "

(67) Special Distribution for "

$\begin{array}{ll}\text { (15) TIS File Room Manuals } & \\ \text { (1) TIS File Record Copy }\end{array}$ 
1

4

1

5

2

1

1

1

Argonne Cancer Research Hospital

Argonne National Laboratory

Armed Forces Special Weapons Project, Washington

Armed Services Technical Information Agency, Dayton

Army $\mathrm{C}_{\mathrm{h}}$ emical Center

Army Medical Research Laboratory

Army Medical Service Graduate School (Commandant)

Atomic Energy Commission, Patent Branch

Atomic Energy Commission, Technical Library

Atomic Energy of Canada Limited

Australian Atomic Energy Commission

Battelle Memorial Institute

Belgium, Centre d'Etudes pour les Applications de l'Energie Belgium, Union Miniere du Haut Katanga Nucleair

Boeing Airplane Company

Brookhaven National Laboratory

Brush Berryllium Company

Bureau of Ships (Code590)

Canadian Joint Staff (Taber)

Carbide \& Carbon Chemicals Company (C-31 Plant)

Carbide \& Carbon Chemicals Company ) $\mathrm{K}-25$ Plant)

Carbide \& Carbon Chemicals Company (ORNL)

Carnegie Institute of Technology

Chalk River Project, Canada

Chicago Patent Group

Columbia University (Dr. Failla)

Columbia University (Dr. Hassialis)

Committee on Atomic Casualties

Consolidated Vultee Alrcraft Corporation

Department of Army, Office of Ordnance Research

Department of Navy (Code 811)

Division of Raw Materials, Denver

Division of Raw Materials, Ishpeming

Dow Chemical Company, Midiand

Dow Chemical Company, Rocky Flats

Eldörado Mining \& Reflining Limited

Frankford Arsenal

General Electric Coppany (ANPP)

General Electric Company (APS)

General Electric Company (RIchland)

Goodyear Atomic Corporation:

Harshaw Chemical Corporation'

Iowa State College

Italy, Centro Informazioni studi Esperienze

Kaiser Engineers

Kirtland Air Force Base

Knolls Atomic Power Laboratory

Lockheed Aricraft Corporation

Los Alamos Scientific Laboratory

Malinckrodt Chemical Works

Mound Laboratory

Natlonal Advisory Committee For Aeronautics, Cleveland 
National Bureau of Standards, Atomic Energy Project National Bureau of Stadiards, Library

Tational Lead Company of Ohio

National Research Conporation

National Research Council, Canada

Naval Medical Research Institute

Naval Research Laboratory

New Brunswick Laboratory

Newport New $S_{h}$ ipbuilding and Dry Dock Company

New Y rk Operations office

North American $\mathrm{A}^{\mathrm{V}}$ iation, Inc.

Nuclear Development Associates, Inc.

Nuclear Métals, Inc..; (Dr: Kaufmann)

Oak Ridge Institute of Nuclear Studies

Phillips Petroleum Company

Princeton University

Public Health Service

Sandia Corporation

The Surgeon General

Tokyo University

United Aircraft Corporation

United Kingdom Scientific Mission

U. S. Geological Survey (RCS-TEPCO), Denver

U. S. Naval Radiological Defense Laboratory

UCLA Medical Research Laboratory

University of California Radiation Laboratory, Berkeley

University of Califofnia Radiation Laboratory, Livermore University of Michigan (Dr. Gomberg)

University of Rochester, Atomic Energy Project

University of Utah

Universtiy of Washington ( $\mathrm{Dr}$. Donaldson)

Vitro Corporation of America

Walter Kidde Nuclear Laboratories, Inc.

Watertown Arsenal

We11, Dr. George I.

Western Reserve University

Westinghouse Electric Corporation

Yale University (Dr. Wadey)

Signal Corps Engineering Laboratories 


\section{ABSTRACT}

The operating characteristics of the SRP Standard Gamma Scintillation Counter and the SRP Special Alpha Scintillation Counter were investigated. Results on both counters are essentially the same. Plateaus are over 200 volts long, with a slope of approximately one per cent per hundred volts. Reproducibility is satisfactory, but the background is high. The coincidence correction is less than one per cent per $10^{5}$ counts per minute.

External Distribution According to TID-4500, 9th Edition 
TABLE OF CONTENTS

INTRODUCTION

SUMMARY AND CONCLUSIONS . . . . . . . . . 4

EXPERIMENTAL WORK .............. 6

General . . . . . . . . . . . 6

Plateaus .................. . . . . 7

Background ................. . . 7

Reproducibility . . . . . . . . . . . . 7

Coincidence Correction ............ 10

BIBLIOGRAPHY . . . . . . . . . . . . 13

APPENDIX ...................... 20

Table of Coincidence Corrections ....... . 2l

\section{LIST OF FIGURES}

Figure 1. Photograph of the Alpha Scintillation

Counter.............. . 14

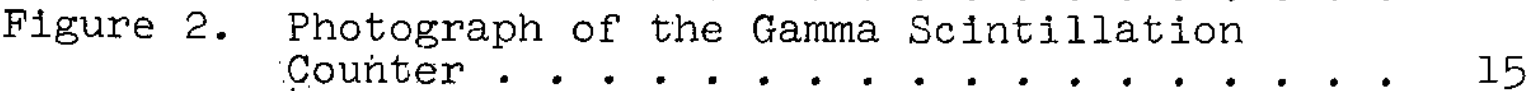

Figure 3. Phosphors Used in the Alpha and

Gamma Scintillation Counters . . . . 16

Figure 4. Scintillation Counter Plateaus : : : : 17

Figure 5. Plot of Counting Rates versus Time

Figure 6. Error Introduced by Using "Tabie of

Coincidence Corrections" to Correct

Observed Count Rate.......... 19 


\section{SRP SCINTILLATION COUNTERS}

\section{INTRODUCTION}

This investigation was part of a program to study the various types of counting equipment procured for use at the Savannah River Plant. The purpose was to determine the characteristics and limitations of the Special Alpha Scintillation Counter, in which the phosphor is three inches in diameter, and of the Standard Gamma Scintillation Counter with a one and one-half-inch phosphor.

The plateau, background, reproducibility, and coincidence correction were investigated. Similar studies of the SRP standard windowless flow counter $(1)$ and the SRP standard Geiger-Mueller Counter $(2)$ were made previously. This investigation concludes the program to study the various types of counting equipment, and no further work is planned.

\section{SUMMARY AND CONCLUSIONS}

The Scintillation Counters were found satisfactory for general use at the Savannah River Plant for counting rates up to $2 \times 10^{5}$ counts per minute. Neither counter is recommended for counting very low level activities.

Plateaus For both alpha and gamma counters, the plateau: is: at least 200 volts long. The location of the enter of the plateau is $950 \pm 50$ volts for all counters tested. The slope at this point is about one per cent per hundred volts.

Backgrounds The background of the Gamma Scintillation counter, inside the standard three-inch iron shield, is high. The lowest background observed was 335 counts per minute and the highest background observed was 523 counts per minute.

The lowest background observed with the Alpha Scintillation Counter was 1.2 counts per minute, and the highest was 18 counts per minute. This relatively high background makes the Alpha Counter unsuitable for counting very low levels of alpha activity (i.e., one to two counts per minute).

Reproducibility with a single scintillation counter, either alpha or gamma, the variation of replicate counts was about that to be expected from statistics. However, one alpha counter, tested over a long period of time, showed a definite drift of counting rate with time. This drift 
was slow enough so that the reproducibility of duplicate or triplicate counts was not affected.

The variation in the counting rate of an alpha source, counted on six counters, was less than five per cent. The variation in the counting rate of a gamma source, counted on six counters, was less than twenty per cent.

Coincidence correction The coincidence correction for either the alpha or gamma scintillation counter can be calculated from the following equation:

$$
\begin{gathered}
N=R+6.335\left(10^{-8}\right) R^{2}+5.553\left(10^{-14}\right) R^{3} \\
\text { where } N=\text { corrected counting rate } \\
\qquad R=\text { observed counting rate }
\end{gathered}
$$

For $R \leq 2 \times 10^{5}$ counts per minute, the expected error in is less than one per cent. A table of coincidence corrections for counting rates up to $5 \times 105$ counts per minute is included in the Appendix to this report. 


\section{EXPERIMENTAL WORK}

GENERAL

The SRP Special Alpha Scintillation Counter is composed of the following major components:

(1) Scaler (Tracerlab Type CC-10)

(I) Scintillation Probe (General Electric Co. Type 122C255GI)

(1) Three-inch Alpha Phosphor (Nuclear Research and Development, Inc.)

(1) Scintillation Planchet Counter (Nuclear Research and Development, Inc.)

Figure 1 is a photograph of the complete Alpha Scintillation Counter.

The SRP Standard Gamma Scintillation Counter is composed of the following major components:

(1) Scaler (Tracerlab Type CC-10)

(1) Scintillation Probe (General Electric Co. Type 122C255GI)

(1) NaI(T1) Crystal (Harshaw Chemical Co., Type

(1) Scintillation Planchet Counter and Donut Shield (Standard Engineering end Machine Co.)

Figure 2 is a photograph of the complete Gamma Scintillation Counter.

A photograph of the phosphor used in each type of scintillation counter is shown in Figure 3 . On the left is the alpha-sensitive zinc sulfide screen, formed on the large end of a conical lucite light pipe. The small end of the light pipe is machined to fit the end of an RCA 5819 photomultiplier tube. The sides of the cone are painted white, to reduce the light losses. On the right is the sodium iodide (thallium activated) crystal with the small lucite light pipe that couples it to the 5819 photomultiplier tube.

Dow Corning "200" fluid having a viscosity of $10^{6}$ centistokes provides optical coupling between the phosphor, light pipe, and photomultiplier tube.

Six different counters of each type were employed in each phase of this investigation. A different scaler and 
probe were used in each counter, but the same six scalers and probes were used for both the alpha and gamma counters. The same phosphor was used for all six counters of each type, and the effect of using different phosphors was determined in a separate experiment.

\section{PLATEAUS}

Plateaus were determined for the six different alpha scintillation counters and the six different gamma scintillation counters. No significant difference was observed between the two types of counters. Plateaus for two counters of each type are plotted in Figure 4. Curves for the other four counters of each type lle between the two curves that are plotted. All plateaus were at least 200 volts long with a slope of approximately one per cent per hundred volts over this range. A potential of 950 volts lies on the plateau of all counters tested.

\section{BACKGROUND}

Backgrounds were relatively high for all twelve counters, These backgrounds were measured at the normal operating voltage, determined by running a plateau. No specific attempt was made to measure either the reproducibility of the background, or the variation of background with photomultiplier anode voltage, What data were obtained, however, indicate that the reproducibility is poor, and that the background varies considerably with anode voltage. The observed backgrounds for the six counters of each type are tabulated below.

\section{OBSERVED BACKGROUND FOR TWELVE SCINTILLATION COUNTERS}

\section{Alpha counters}

\begin{tabular}{cc}
$\begin{array}{c}\text { Counter } \\
\text { Number }\end{array}$ & $\begin{array}{c}\text { Counts } \\
\text { per } \\
\text { Minute }\end{array}$ \\
\cline { 2 - 3 } 1 & 18 \\
2 & 1.2 \\
3 & 15 \\
4 & 3.7 \\
5 & 12 \\
6 & 12
\end{tabular}

Gamma Counters

\begin{tabular}{|c|c|}
\hline $\begin{array}{l}\text { Counter } \\
\text { Number }\end{array}$ & $\begin{array}{l}\text { Counts } \\
\text { per } \\
\text { Minute }\end{array}$ \\
\hline $\begin{array}{r}7 \\
8 \\
9 \\
10 \\
11 \\
12\end{array}$ & $\begin{array}{l}512 \\
459 \\
523 \\
335 \\
429 \\
424\end{array}$ \\
\hline
\end{tabular}

\section{REPRODUCIBILITY} The colncidence corregtion was determined by making
324 ten-minute counts. Nine co gamma sources and nine Pu alpha sources were each counted three times on six different counters. These data were analyzed to see if their: variations were statistical, by using a variance ratio (F) test, in the 
following manner.

For each of the 108 sets of three counts, the three deviates were calculated:

where

$$
t_{i}=\sqrt{\frac{N}{N-1}} \times \frac{M_{i}-\bar{M}}{\sqrt{M}} \quad i=1,2,3
$$
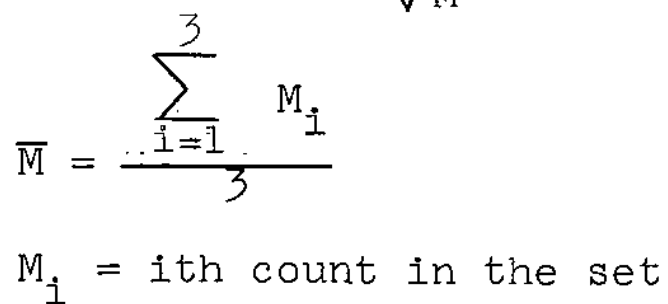

$\mathrm{N}=$ number of counts in each set (in this case $N=3)$.

From these deviates, the variance was calculated:

$$
S^{2}=F=\frac{\sum_{i=1}^{324} t_{i}{ }^{2}}{324}
$$

For these data, $F=1.17$, which is to be compared with the value of 1.21 isted in a standard $F$ table $(3)(4)$ for the oneper cent confidence limit. The low value of $F$ indicates that the observed variations could be statistical in nature.

In another test of the same data, the relation (3),

$$
\sigma=\sqrt{\frac{\mathrm{N}}{\mathrm{N}-1}} \times \frac{1.645}{\sqrt{\mathrm{M}}}
$$

was used to calculate the expected deviation from the average at the 90-per cent confidence level. $\bar{M}$ is the average number of counts per observation, and $\mathrm{N}$ is the number of observations. Of the 324 counts that were included in this series, 317 (98\%) were within the deviation, $\sigma$.

In another series of counts a single co ${ }^{60}$ source was counted ninety-four times on the same counter. Included were one 1000-minute count, three 100-minute counts, thirty 10minute counts, thirty 3-minute counts, and thirty l-minute counts, These data were statistically analyzed with the $x^{2}$ test (5). The results of this analysis are listed in the following table: 


\section{VALUES OF $\chi^{2}$ CALCULATED FROM THIRTY OBSERVATIONS}

Length of Count
(minutes)

1

3

10

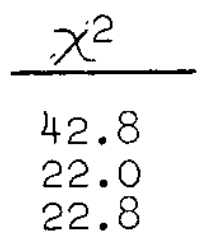

For a purely statistical variation, $\dot{\chi}^{2}$ should be less than 39.1 for thirty observations $(5)$ with a confidence limit of 0.9 . Hence the variation of replicate one-minute counts is greater than would be expected from statistics. The variation of replicate three-minute and ten-minute counts is within that to be expected from statistics.

The decrease in the observed gounting rate with increasing time of count, noted elsewhere (1)(2), is shown by this series of counts to a much lesser degree. Timing errors, characteristic of the first Tracerlab CC-10 scalers, have been corrected in later models. One of these later models was used in collecting these data.

In a similar series of counts, a $\mathrm{Pu} 239$ alpha source was counted ninety-three times. Included were one 1000-minute count, two 100-minute counts, thirty 10-minute counts, thirty 3-minute counts, and thirty 1 -minute counts. The data from the one-minute and three-minute counts were statistically analyzed by the $x^{2}$ test, with the following results:

$$
\begin{array}{cc}
\text { VALUES OF } \chi^{2} \text { CALCULATED FROM THIRTY OBSERVATIONS } & \text { Length of Count } \\
\frac{\begin{array}{c}
\text { (minutes) } \\
1
\end{array}}{3} & \frac{x^{2}}{33.4} \\
& 30.4
\end{array}
$$

The variation of replicate one-minute and three-minute counts is, therefore, within that to be expected from statistics. The data from the ten-minute counts were not statistically analyzed. Visual inspection of the data indicated that the counter was not working properly. The counting rate of the source decreased with time. This effect was not due to radioactive decay or loss of activity, and must be attributed to the counter.

To investigate this decrease in counting rate with time more thoroughly, a. long series of counts was made. Included were one 5400-minute count, six 1000-minute counts, six 100-minute counts, and one hundred twenty 10-minute counts. Results are summarized in Figure 5. The counting rate decreased at the beginning of the series, but appeared to increase again at the end of the series. During this series, 
the counter was running almost continuously for eleven days. The 5400-minute count was taken over a week end and the 1000-minute counts were overnight counts.

Two values in this series were rejected. Their deviation from the average exceeded Chauvenet's criteria for the rejection of suspected observations (5).

These data were statistically analyzed in two ways. First a value of $\chi^{2}=285$ was calculated for the 118 tenminute counts. For purely statistical,yariations, $\chi^{2}$ should be less than 140 for 118 observations (5) with a confidence limit of 0.9 . The high value of $\chi^{2}$ merely rewemphasized the drift in counting rate apparent from Figure 5 . These data were then broken up into ten groups of ten 10-minute counts and two groups of nine 10-minute counts, the latter corresponding to the two rejected counts. A variance ratio (F) test was applied to these twelve sets of data, and a value $F=1.23$ calculated. This is to be compared with the value $F=1.38$ listed in a standard $F$ table for the one-per cent confidence limit $(4)(5)$. The low value of $F$ indicates that the drift in counting rate is slow enough that the statistics of a group of ten replicate ten-minute counts are not greatly affected.

The data collected to calculate the coincidence correction were also used to determine the agreement among various counters. Nine Pu239 alpha sources and nine co60 gamma sources were each counted on six counters. The correct counting rate was taken as the average of three ten-minute counts.

The maximum variation in counting rate among the six alpha counters for any single source was 2.3 per cent. In a separate experiment, six different phosphors were used with the same counter and alpha source. The counting rate among the six phosphors differed by a maximum of 2.2 per cent. Therefore, the counting rate of a source measured with one alpha scintillation counter may differ as much as five per cent from the counting rate measured with another alpha scintillation counter.

The maximum variation in the counting rate among the six gamma counters for any single source was six per cent. In another separate experiment, nine different phosphors were used with the same counter and gamma source. The counting rate among the nine phosphors differed by as much as ten per cent. In general, therefore, agreement of better than five per cent among counters can not be expected, and differences of more than fifteen per cent are possible.

COINCIDENCE CORRECTION

The method of paired sources (6) was used to determine the coincidence correction. A relationship between 
the observed counting rate " $\mathrm{R}$ " and the true counting rate " $\mathrm{N}$ " is:

$$
N=R+\tau R^{2}+\nu R^{3}
$$

Three "paired" sources were counted, and the values of $\tau$ and $\nu$ which best fit the experimental data were determined by a method of least squares.

below:

The values appropriate for each counter are summarized ALPHA COUNTERS

Counter

Number

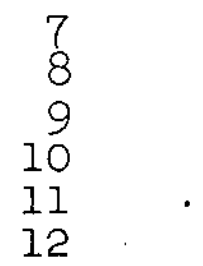

Average of six

alpha counters $\underline{\tau \times 10^{8}}$

10.504

5.585

10.515

9.626

6.396

6.062

8.115

GAMMA COUNTERS

Average of six

gamma counters

1.046

1.467

6.467

5.528

7.086

5.372

4.554

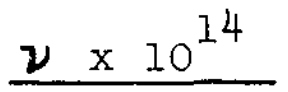

0.525

8.738

4.290

2.982

5.300

8.280

5.019

Average of twelve counters

6.335

13.073

10.443

9.245

2.781

0.243

0.733

6.086

A comparison was then made between each of the twelve specific equations calculated for the twelve counters, and the general equation calculated from the average of the data from the twelve counters. It was assumed that the "true" counting rate was the observed counting rate corrected by the specific equation for the particular counter. Calculations were then made to determine the error introduced in the "true" counting rate, for each of the twelve counters, when the observed counting rate was corrected by using the general equation. Figure 6 is a plot of this error versus counting 
rate. At counting rates up to $2 \times 10^{5}$ counts per minute, the maximum error introduced by using the general equation is less than one per cent.

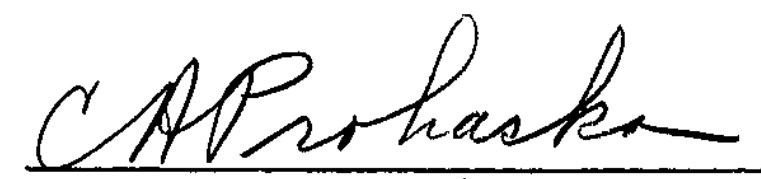

C. A. Prohaska

Instrument Development Division 


\section{BIBLIOGRAPHY}

1. Prohaska, C. A. The SRP Standard Windowless Flow Counter. E. I. du Pont de Nemours \& Co., DP-45, April, 1954.

2. Prohaska, C. A. The SRP Standard Geiger-Mueller Counter. E. I. du Pont de Nemours \& Co., DP-61, May, 1954.

3. Clark, C. E. An Introduction to Statistics. New York: John Wiley \& Sons, Inc. (1953), Table V, Page 252.

4. Dixon, W. J., and Massey, F. J. Jr. Introduction to Statistical Analysis. New York: McGraw-Hill Book Co., Inc. (1951), Table 7C, page 312.

5. Jarrett, A. A. Statistical Methods Used in the Measurement of Radioactivity. United States Atomic Energy Commission, AECU-262 (MonP-126), June 1946.

6. Kohman, T. P. A General Method for Determining Coincidence Corrections of Counting Instruments. United States Atomic Energy Commission, MDDC-905, June 13, 1945. 


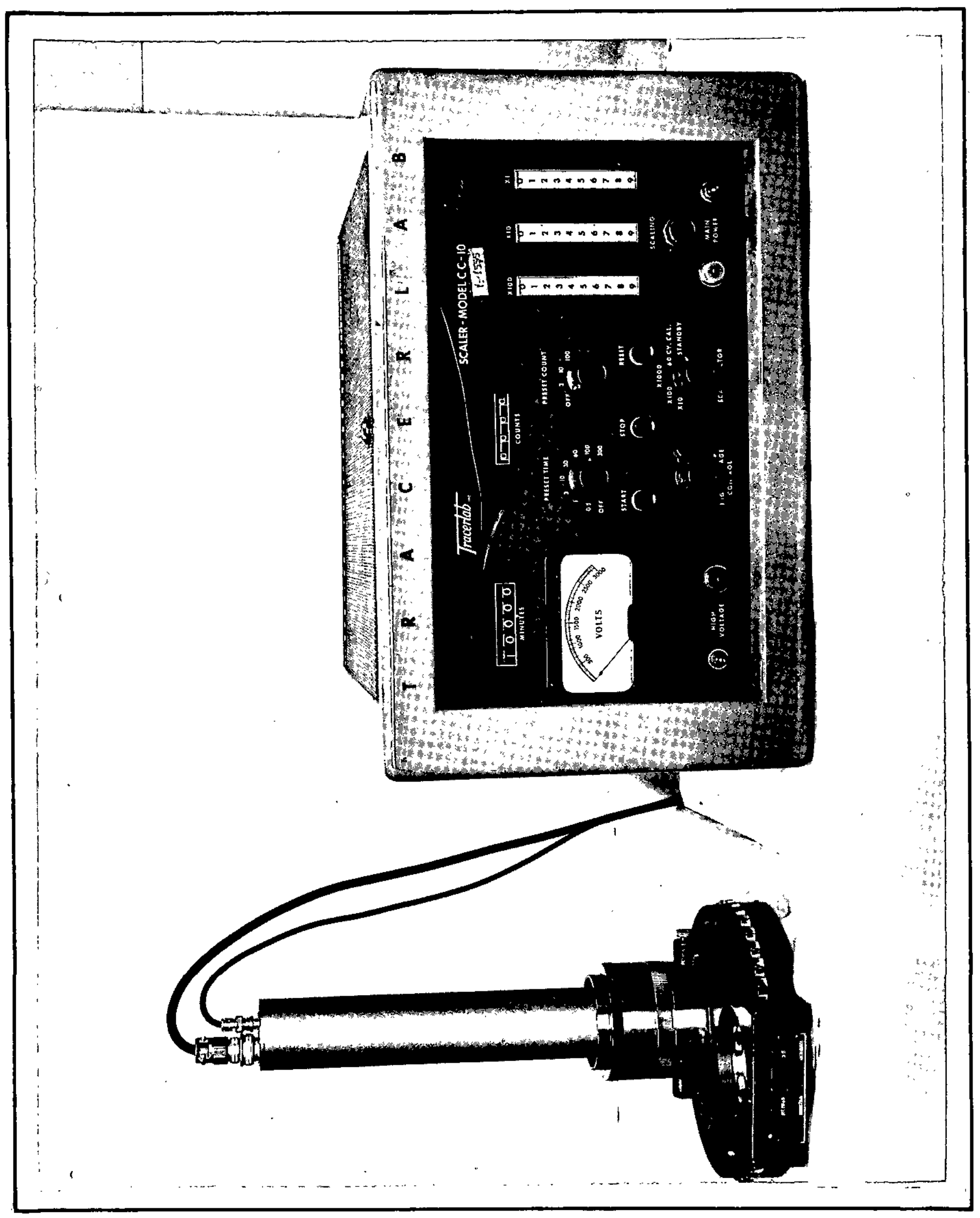

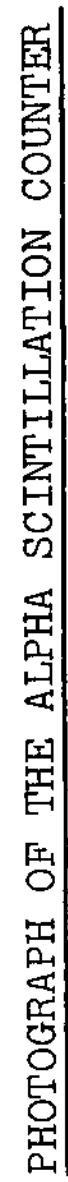




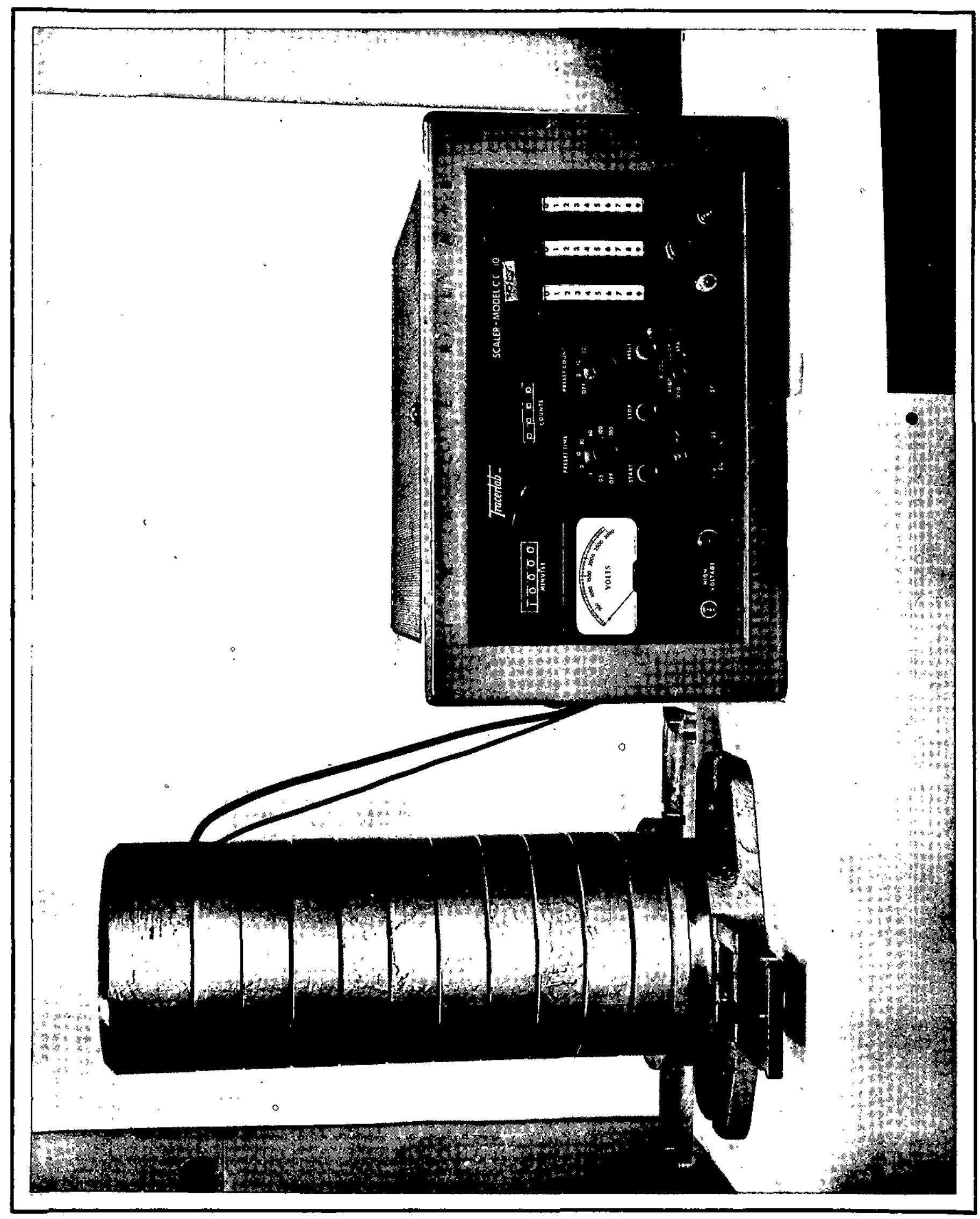

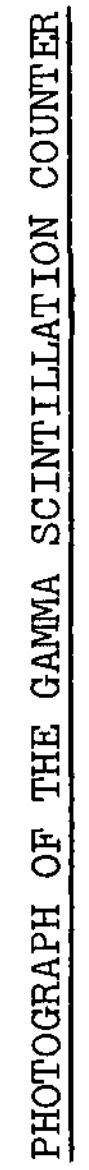




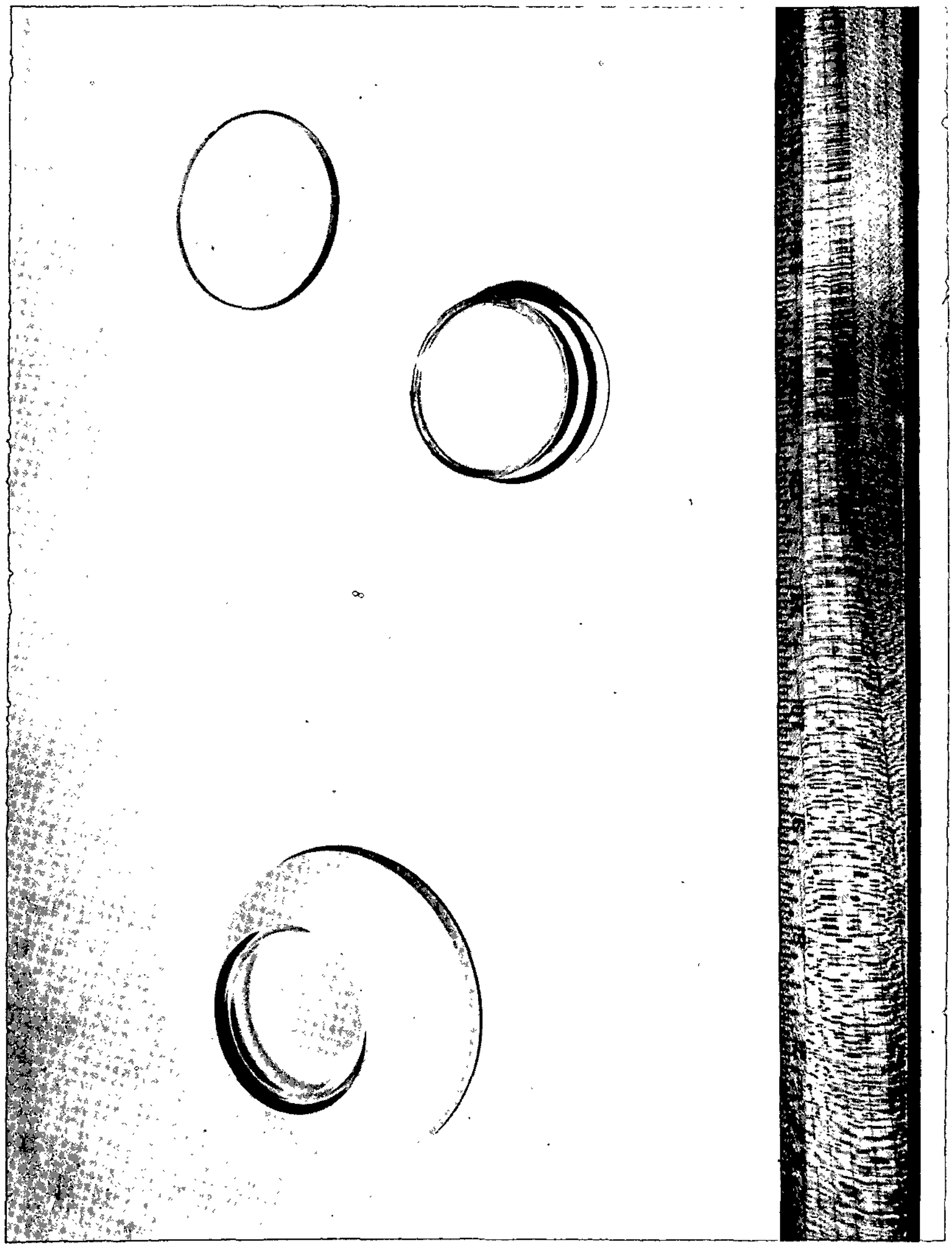

02 


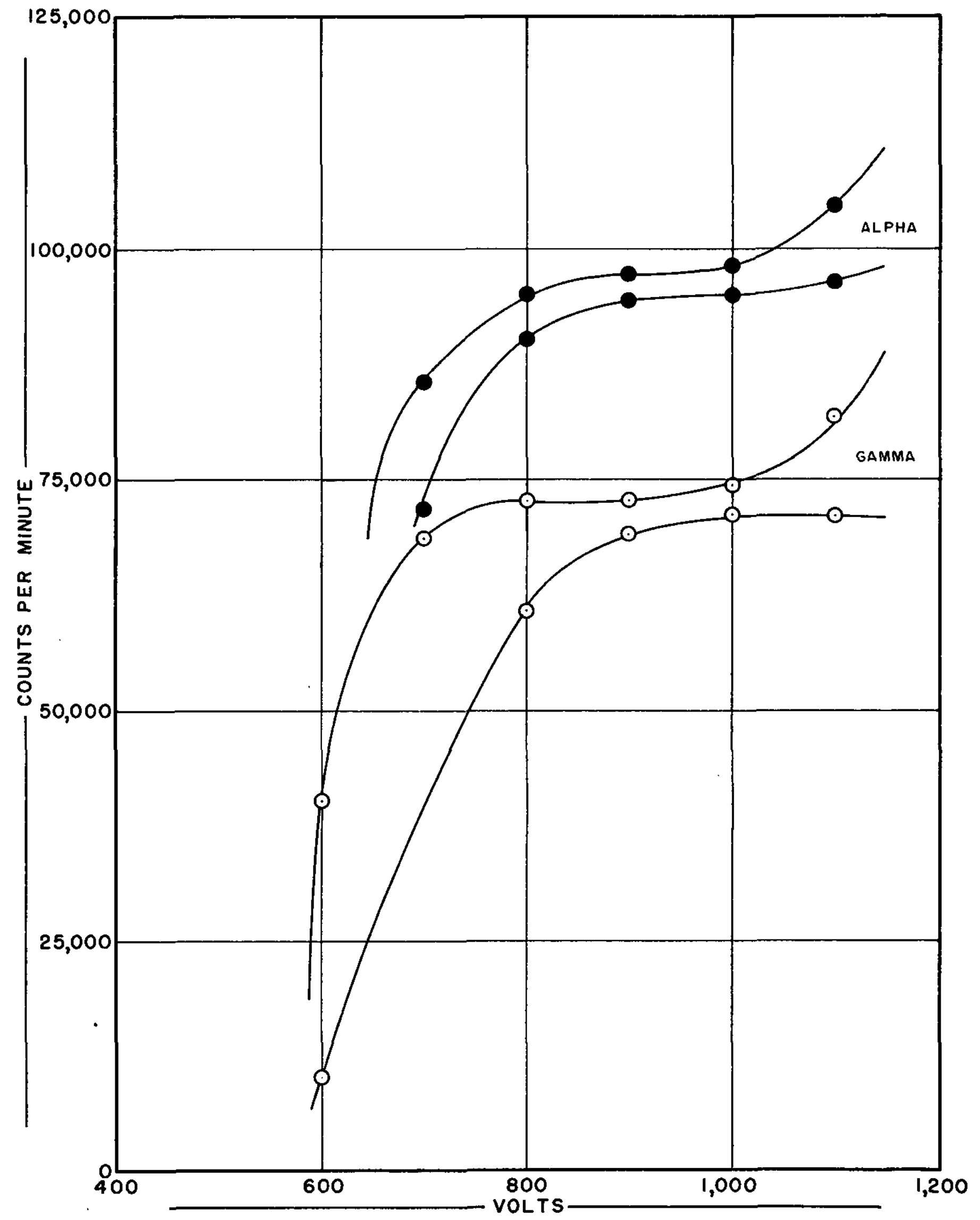




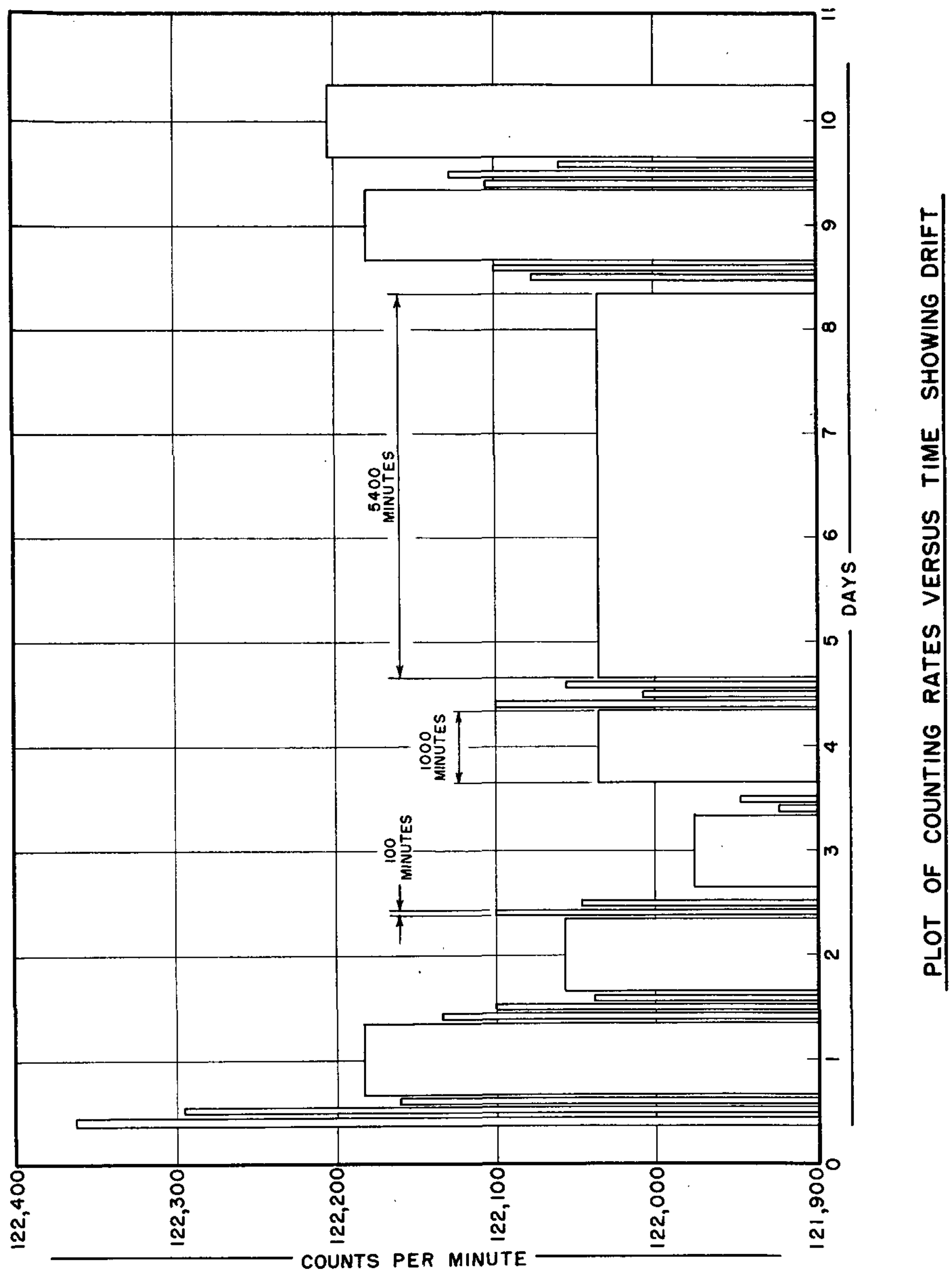


응

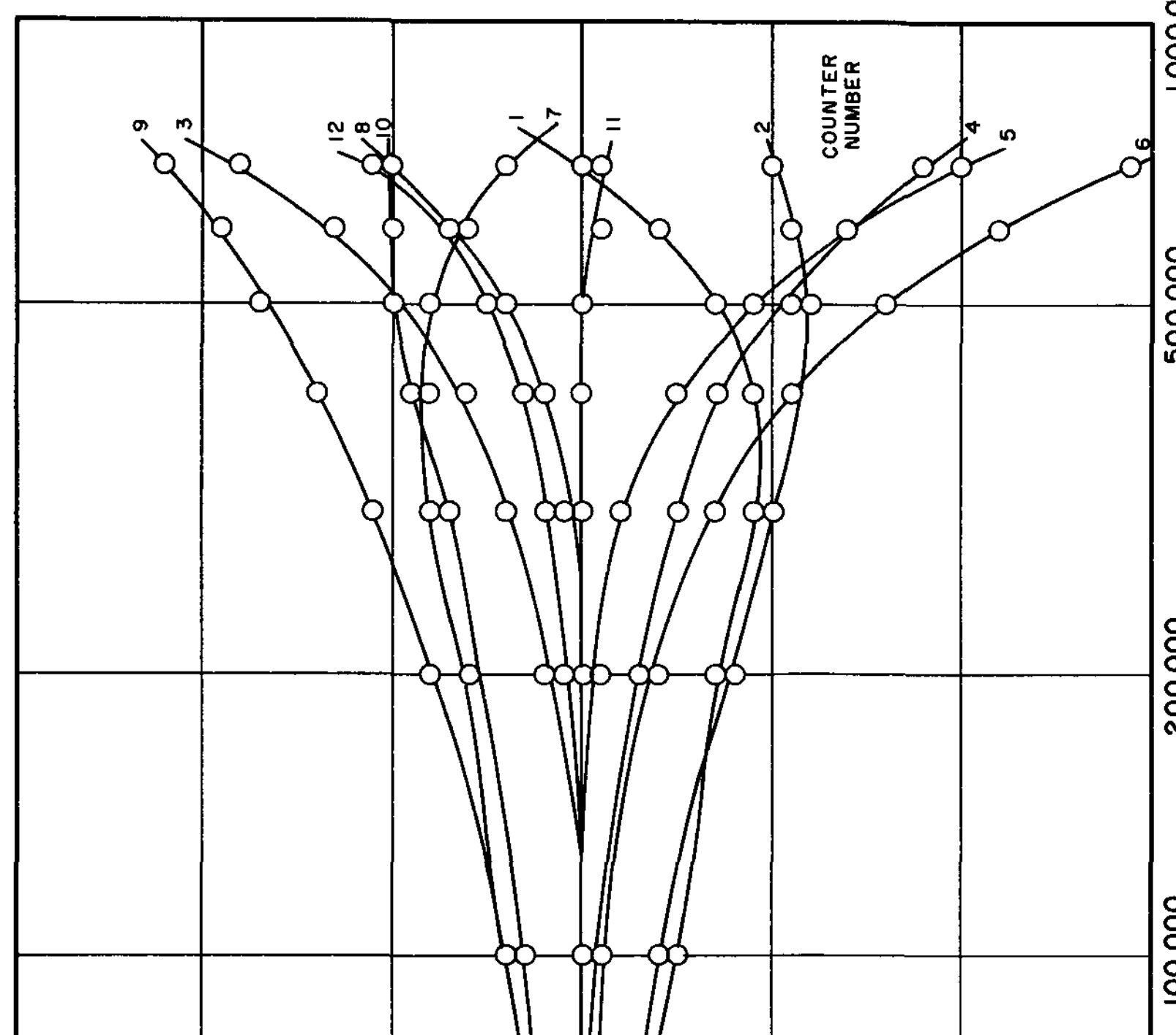

응

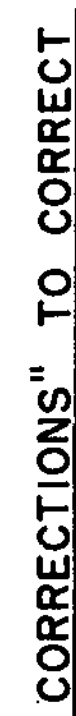

岁|

in

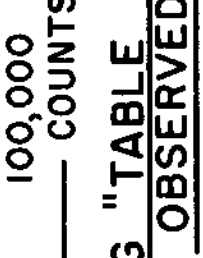

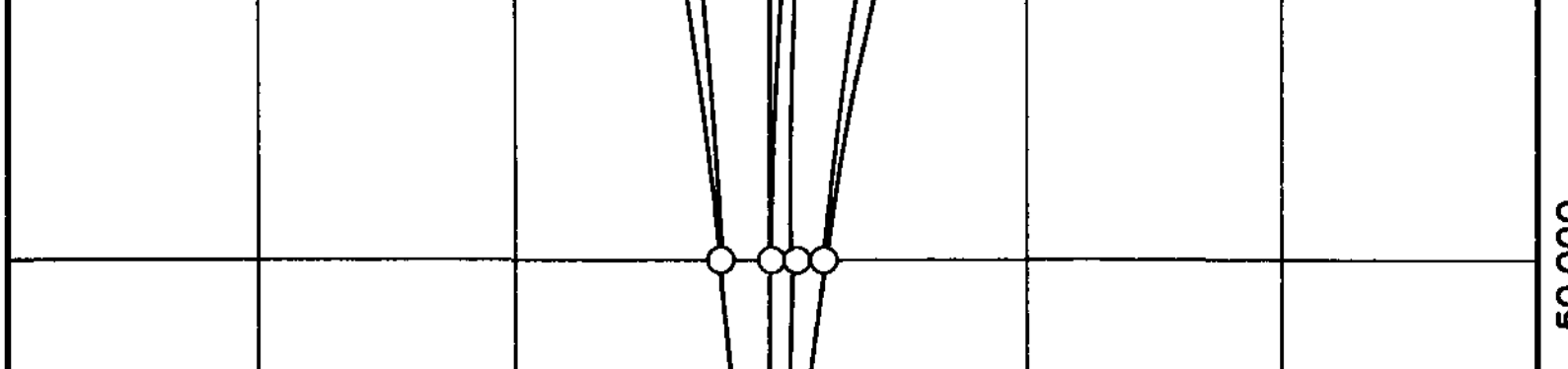

웅 


\section{APPENDIX}

The attached table shows coincidence corrections versus observed counting rate for both the alpha and gamma scintillation counters. The equation:

$$
N=R+6.335\left(10^{-8}\right) R^{2}+5.553\left(10^{-14}\right) R^{3}
$$

was used to calculate these corrections. $R$ is the observed. counting rate, and $\mathrm{N}$ is the "true" counting rate. The table lists the correction to be added to the observed counting rate, in counts per minute, to obtain the "true" counting rate. Values for the observed counting rates between 10,000 and 500,000 counts per minute are listed in units of 1000 counts per minute. Interpolation in the table is not necessary since a maximum error of 0.01 per cent is introduced by reading the coincidence correction to the nearest thousand observed counts per minute. The vertical column of numbers at the left-hand edge gives the observed counting rate in units of 10,000 counts per minute. Intermediate values in units of 1000 counts per minute run across the top of the table. The following example illustrates the use of the table:

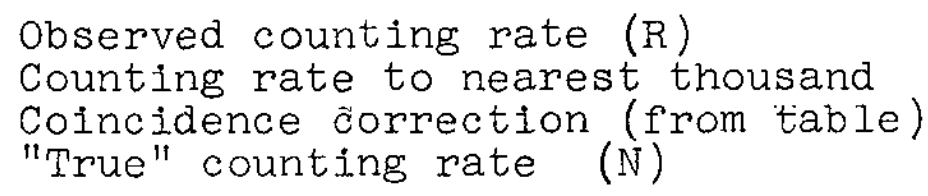

Observed counting rate (R) Counting rate to nearest thousand Coincidence correction (from table) "True" counting rate (N)

$157,203 \mathrm{c} / \mathrm{m}$
$157,000 \mathrm{c} / \mathrm{m}$
$1,776 \mathrm{c} / \mathrm{m}$
$158,979 \mathrm{c} / \mathrm{m}$ 


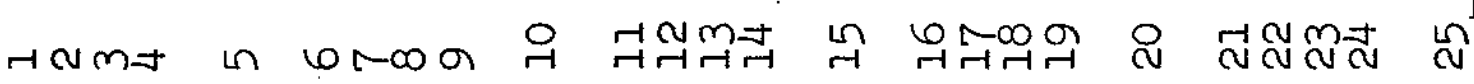

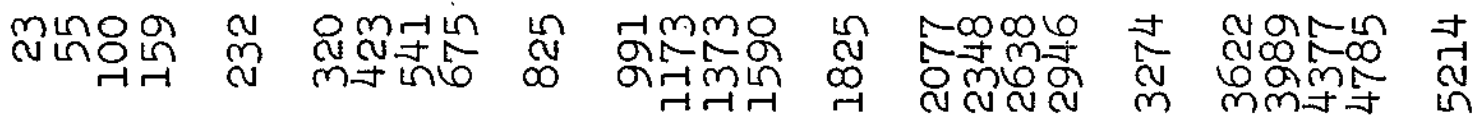

HनINA

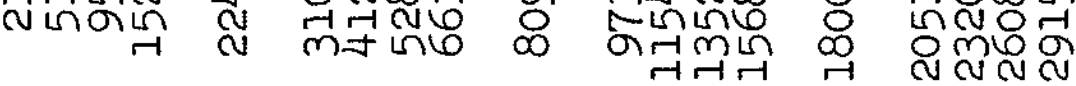

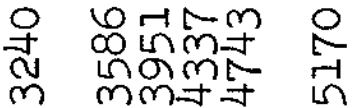

कर

में ơ

옹ำ

i

orimin ना मी

i Nin Nก๊

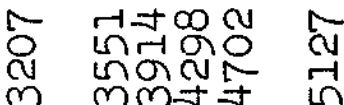

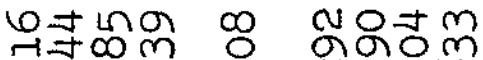

नअ $\underset{\sim}{\mathrm{N}}$

ำ

$\infty$ ब담 जित्ञलत

in oingr न बूलूñ

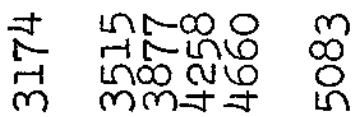

걱ㅇㅇㅇ

กิ

mo요

$\stackrel{m}{1}$

ูํํㅇำ

๙에요

ब न. नूल्खि

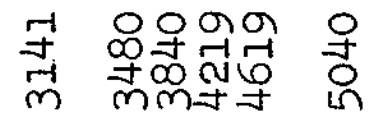
mํํ스

억ㄱ

लैखิ

$\exists \infty \rightarrow$ in

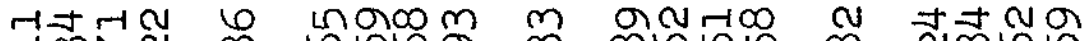

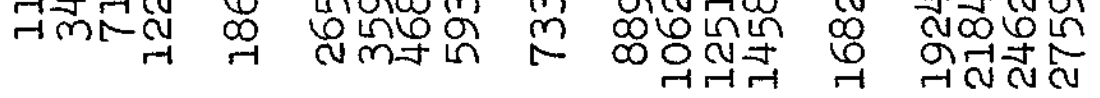

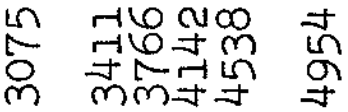

arto

$\stackrel{9}{\sim}$

-ana

\section{$\prod_{i=1}^{\infty}$}

$m=06$ ingun

cợ त可

尔

gîm $\infty$ in

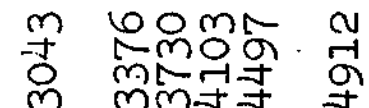

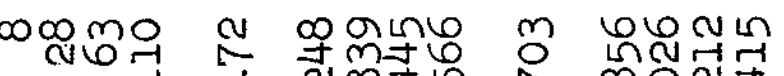
लif $\rightarrow \rightarrow$ तก $m$ in

O 어멱

m 츠용

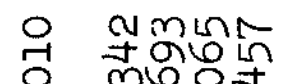
क्ते

m의

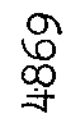

ตำ

$\underbrace{n}_{-1}$

워쎠ํำ

@

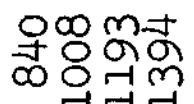

$\underset{r}{\vec{b}}$

ब나잉

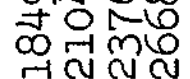

๙

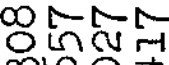
mó

\begin{tabular}{c} 
N \\
\multirow{1}{*}{}
\end{tabular} 


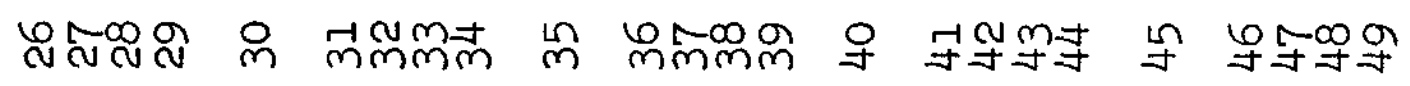

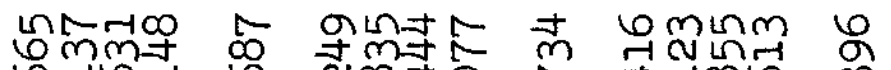

ดन

nub

O

$\stackrel{m}{\sim}$

능요

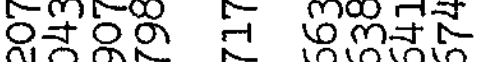

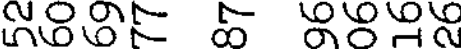

줏ํำ

agrin

a NinNo

음

5 तन

motin

mํำ

$\underset{m}{\stackrel{n}{*}}$

$+\infty 9 \infty$

ํํㅇำ

(o)

rin

-100

ningt

o

(1)

-

ำ

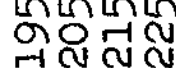

ㅇํำmm

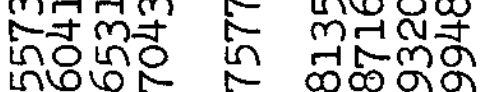

8
8
0

이요

농ำ

$\underset{\substack{m\\}}{\stackrel{\infty}{a}}$

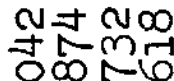

은

ता $\rightarrow$ -

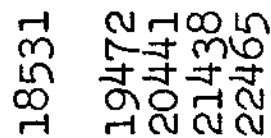

m户नt m

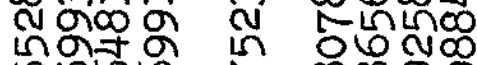

i) $g \circ \mathrm{mm}$

in ภำ

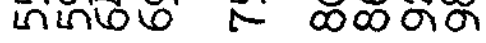

개표

辇

Hoino

$600 \pm$

aำ in

$\infty 6 m$ om

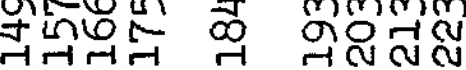

Nora क Nकto

6. O

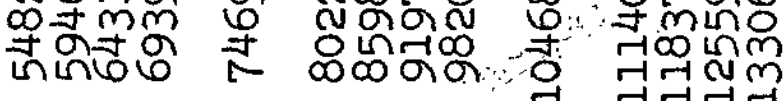

@

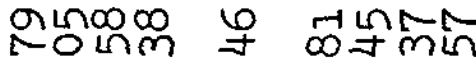

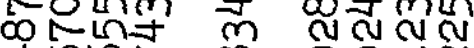

जी

Moñ in inglo

mo 0

$\rightarrow \infty \mathrm{m}^{\circ}$

装

onmin

$\underset{1}{0}$

N66 NoO OIN

뭉

कNํำ - $60 \mathrm{~m}$ जा

กิ

6 잉

त्- $\mathrm{H}$

लमतन

겅대

भญ तू

NHon minmm

क्ष

9댄 ininio

$m$ ỡo

m $\pm 10 \mathrm{~min}$

m gीना⿰丿⿺⿻⿻一㇂㇒丶𠃌⿴囗十

न्नित्नल

ल)

$\operatorname{mos} 0$

- molo

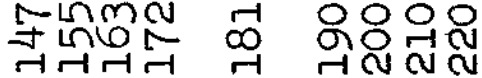

N NOWH

o बinm

푸 $m$ A

† 00 엥 moñ $m$ क्ष

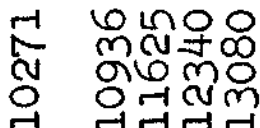

in ming

minor

जी

$\stackrel{1}{0}$

onmos

on

$\infty$ on

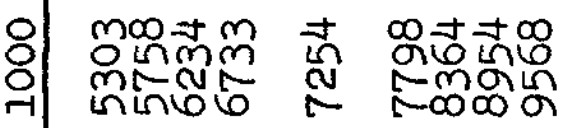

$\stackrel{6}{0}$

क जिएव

$\infty$ inㅇํㅇ

กN

6

m nmos

a mowo

은



$\infty$ तl फ़न 10 ining
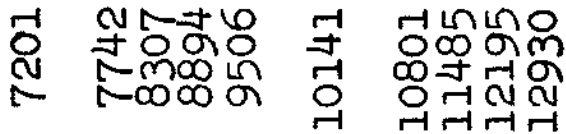

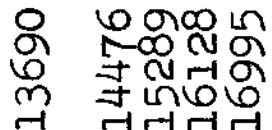

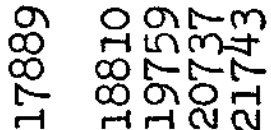

